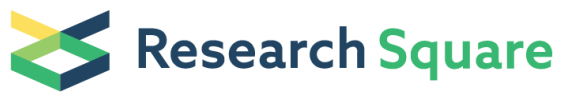 \\ Preprints are preliminary reports that have not undergone peer review. \\ They should not be considered conclusive, used to inform clinical practice, \\ or referenced by the media as validated information.
}

\section{Improvement in Growth and Yield Attributes of Cluster Bean Through Optimization of Sowing Time and Plant Spacing Under Climate Change Scenario}

Ibrar Hussain

Department of Agronomy, MNS- University of Agriculture, Multan

Muqarrab Ali

Department of Agronomy, MNS- University of Agriculture, Multan

Abdullah Modaihsh

Department of Soil Sciences, College of Food and Agricultural Sciences, King Saud University, P.O. Box 2460, Riyadh 11451

Khurram Shahzad

Plant Nutrition Section, Mango Research Institute, Multan

Omer Farooq

Department of Agronomy, Bahauddin Zakariya University, Multan

\section{Shahid Iqbal}

Department of Agronomy, MNS- University of Agriculture, Multan

\section{Fahim Nawaz}

Department of Agronomy, MNS- University of Agriculture, Multan

\section{Shakeel Ahmad}

Department of Soil Science, MNS- University of Agriculture, Multan

\section{Lal Hussain Akthar}

Regional Agriculture Research Institute, Bahawalpur

\section{Muhammad Mazhar Iqbal}

Soil and Water Testing Laboratory, Chiniot

\section{Shah Fahad}

Hainan Key Laboratory for Sustainable Utilization of Tropical Bioresource, College of Tropical Crops, Hainan University, Haikou 570228

\section{Adel Ghoneim}

Department of Soil Sciences, College of Food and Agricultural Sciences, King Saud University, P.O. Box 2460, Riyadh 11451

Subhan Danish ( $\sim$ sd96850@gmail.com)

Department of Soil Science, Faculty of Agricultural Sciences and Technology, Bahauddin Zakariya University, Multan

\section{Süleyman TABAN}

Department of Soil Science and Plant Nutrition, Faculty of Agriculture, Ankara University, 06110 Diskapi-Ankara

\section{Rahul Datta}

Department of Geology and Pedology, Faculty of Forestry and Wood Technology, Mendel University in Brno, Zemedelska1, 61300 Brno

\section{Research Article}

Keywords: Cyamopsis tetragonoloba L., growth attributes, planting density, sowing time

Posted Date: January 13th, 2021

DOI: https://doi.org/10.21203/rs.3.rs-142811/v1 
License: (c) (i) This work is licensed under a Creative Commons Attribution 4.0 International License. Read Full License

Version of Record: A version of this preprint was published at Saudi Journal of Biological Sciences on November 1st, 2021. See the published version at https://doi.org/10.1016/j.sjbs.2021.11.018. 


\section{Abstract}

Cluster bean (Cyamopsis tetragonoloba L.) yield have plateaued due to reduction in rainfall and rise in temperature. Therefore, its production cycle could not get appropriate water and temperature. It becomes important to standardize sowing time and plant spacing of cluster bean in changing climate scenario to get higher productivity. Therefore, a field study was conducted to evaluate the effect of four sowing times ( $15^{\text {th }}$ May, $1^{\text {st }}$ June, $15^{\text {th }}$ June, and $1^{\text {st }}$ July) and three plant spacings $(10,12$ and $15 \mathrm{~cm})$ on crop growth, yield, and physiological functions of cluster bean genotype BR-2017. The sowing times $\left(15^{\text {th }}\right.$ May, $1^{\text {st }} \mathrm{June}, 15^{\text {th }} \mathrm{June}$, and $1^{\text {st }}$ July) were placed in the main plot while plant spacing $(10,12$ and $15 \mathrm{~cm})$ were maintained in subplots. Results showed that $1^{\text {st }}$ June sowing performed better over $15^{\text {th }}$ May, $15^{\text {th }}$ June, and $1^{\text {st }}$ July while plant spacing $15 \mathrm{~cm}$ about in all sowing times showed higher results on growth and yield parameters of cluster bean over plant spacing 10,12, and $15 \mathrm{~cm}$. The $1^{\text {st }}$ June sowing time at 15 $\mathrm{cm}$ plant spacing showed $8.0,22.7$, and $28.5 \%$ higher grains pod ${ }^{-1}$ as compared to $15^{\text {th }}$ May, $15^{\text {th }}$ June, and $1^{\text {st }}$ July sowing respectively. The chord diagram clearly indicates that the crop has received optimum environmental conditions when sown $1^{\text {st }}$ June over other sowing times. In conclusion, $1^{\text {st }}$ June sowing with $15 \mathrm{~cm}$ plant spacing could be a good option to achieve maximum productivity of cluster bean under changing climate scenario.

\section{Introduction}

Cluster bean (Cyamopsis tetragonoloba L.) is mainly grown in arid and semi-arid areas of India, Pakistan, South Africa and United States ${ }^{1,2}$. Cluster bean pods are used as vegetable. Galactomannans is a polysaccharide which is extracted from guar and known as guar gum ${ }^{3}$. Grain of cluster bean are made of germ (41-46\%), endosperm (34-43\%) and hull (13-18\%) ${ }^{4}$. In addition, cluster bean is grown as a green manuring crop in different parts of the world. The husk of cluster bean is used for cattle feed because it contains high protein contents ${ }^{5}$. Cluster bean is also a good source of fats, proteins, phosphorous, calcium, and mineral salts ${ }^{6,7}$. Cluster bean as a leguminous crop helps in fixation of atmospheric nitrogen that contributes towards the soil fertility ${ }^{5}$.

Sowing time and planting geometry plays an important role in production of cluster bean ${ }^{8}$. Sowing time affects the whole plant growth cycle including seed germination, seedling emergence, plant vegetative growth, flowering, pod formation, grain filling, and crop maturity. When crop is sown early, plants makes its vegetative phase prolong as compare to reproductive phase depending upon atmospheric temperature and rainfall of the area ${ }^{9}$. But when crop is sown late, flowering comes earlier and plants could not complete its normal vegetative phase ${ }^{10}$. The increase in temperature accelerates the phenological cycle of plant and this leads decline in yield of crop ${ }^{11}$. Therefore, cluster bean production is directly related to annual rainfall, temperature and humidity of an area ${ }^{12}$. Sowing time play a vital role in increasing or decreasing of crop yield ${ }^{13}$. Hussain et al. ${ }^{14}$ found that germination of mung bean crop was affected due to early sowing because of unfavorable environmental conditions during crop cycle. Different sowing times are practiced in different parts of the world. The months of May and August are considered to be the best sowing time for yield purpose in Pakistan while at Mediterranean environment of Italy mid-May considered most beneficial sowing time to obtain higher yield ${ }^{15}$. In the south west of United States sowing is conducting between May to early June ${ }^{16}$.

In addition, sowing time, planting density is also important in production of cluster bean. Improper planting geometry of crop increase space, water, nutrients, and light competition among plants, increase weed density, and create hurdle in the cultural practices. The low plant population due to wider spacing causes low yield and ultimately economical loss to the farmers. Moreover, Intra crop competition enhanced due to variation in plant spacing ${ }^{17}$. Experiments on plant and row spacing in the different soil and environmental conditions showed higher crop yield were achieved by maintaining proper planting density ${ }^{18}$. Stem length, and biomass and portion in study of Blumenthal et al. ${ }^{19}$ are increased by increasing the plant spacing. ${ }^{20}$. Kumar and Ram ${ }^{7}$ found that cluster bean grown at $70 \mathrm{~cm}$ plant spacing showed higher yield as compared to one grown on 75 and $100 \mathrm{~cm}$ spacing.

In another study of Choy et al. ${ }^{21}$ lower plant spacing showed higher branches, leaves and plant height as compared to wider branches. Blumenthal et al. ${ }^{19}$ found maximum productivity of Indian bean with planting geometry $45 \times 20 \mathrm{~cm}$. Dhedhi et al. ${ }^{22}$ carried out an experiment in India to evaluate the response of various sowing times and planting density on cluster bean yield. The findings showed that sowing time (1st July) and planting density $30 \times 10 \mathrm{~cm}^{2}$ achieved the maximum cluster bean yield as compared to other sowing times. In controversy of sowing time and planting spacing, therefore, it becomes important to

Page $3 / 22$ 
standardized the sowing time and plant spacing in changing climate scenario. Therefore, this study was planned with main objective to optimize the sowing time and planting spacing in Multan, Pakistan to achieve maximum productivity of cluster bean.

\section{Materials And Methods}

\subsection{Experimental Site}

Experiment was carried out in Agronomic Research Station of MNS-University of Agriculture, Multan, Pakistan that is located at $32.14{ }^{\circ} \mathrm{N}$ latitude and $73.65^{\circ} \mathrm{E}$ longitude during the Kharif summer season 2019 . Field experiment was layout in arid climatic conditions (Fig. 1). Soil texture was loamy which contains $\mathrm{pHs}(8.2)^{23}$ organic matter $(0.50 \%)^{24}, \mathrm{ECe}\left(2.45 \mathrm{dS} \mathrm{m}^{-1}\right)^{25}$, exchangeable potassium $\left(215 \mathrm{mg} \mathrm{kg}^{-1}\right)^{26}$ and available phosphorus $\left(7.15 \mathrm{mg} \mathrm{kg}^{-1}\right)^{27}$ (Table 1).

Table 1

Soil properties of experimental site

\begin{tabular}{|c|c|c|c|c|c|c|c|}
\hline Depth & 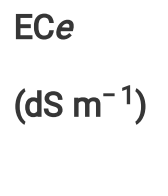 & $\mathrm{pHs}$ & $\begin{array}{l}\text { Organic } \\
\text { Matter } \\
(\%)\end{array}$ & $\begin{array}{l}\text { Available } \\
\text { Nitrogen } \\
\left(\mathrm{mg} \mathrm{kg}^{-1}\right)\end{array}$ & $\begin{array}{l}\text { Available } \\
\text { Phosphorus } \\
\left(\mathrm{mg} \mathrm{kg}^{-1}\right)\end{array}$ & $\begin{array}{l}\text { Available } \\
\text { Potassium } \\
\left(\mathrm{mg} \mathrm{kg}^{-1}\right)\end{array}$ & Texture \\
\hline $0-15 \mathrm{~cm}$ & 2.45 & 8.2 & 0.50 & 100 & 7.15 & 215 & Sandy loam \\
\hline $15-30 \mathrm{~cm}$ & 2.54 & 8.00 & 0.46 & 50 & 5.46 & 180 & \\
\hline
\end{tabular}

\subsection{Treatments}

The treatments of this study include four sowing times (15th May, 1st June, 15th June and 1st July), and variety (BR-2017), and three plant spacings $(10,12.5$ and $15 \mathrm{~cm})$. The sowing times in main plot while in sub plot plant spacing were applied.

\subsection{Field Experiment}

Seedbed was set up by developing the field for 3-4 times with farm tractor mounted cultivar each followed by planking. The beds were set up by utilizing bed shaper. A soaking irrigation was applied seven days before planting of cluster bean seed to keep the exploratory land soft and moist to get ready root and seed bed. The treatments were applied according to split plot arrangement RCBD design. Cluster bean variety BR-2017 was sown in 2 nd week of May using seed rate $20 \mathrm{~kg} \mathrm{ha}^{-1}$ on beds. The plant $\times$ plant and row $\times$ row spacing of 10,12 and $15 \mathrm{~cm}$ were maintained respectively. Thinning of the crop was done 25 days after sowing (DAS) to maintain the plant population as per treatments. Recommended dose of NPK fertilizers for cluster bean $(20,40$ and $20 \mathrm{Kg}$ $\mathrm{ha}^{-1}$ ) were applied. All Phosphorus was applied at sowing while Nitrogen was applied at sowing and flowering stages. Sources of fertilizers used were urea $(46 \% \mathrm{~N})$, di-ammonium phosphate $\left(18 \% \mathrm{~N}: 46 \% \mathrm{P}_{2} \mathrm{O}_{5}\right)$ and SOP $\left(50 \% \mathrm{~K}_{2} \mathrm{O}\right)$. first irrigation was applied 3 days after sowing and 2 nd irrigation was applied 10 days after first irrigation. Crop was harvested carried out manually. Weed were controlled by manually as well as use of weedicides. Cluster bean harvesting was done when more than $80 \%$ pods were matured. Harvesting was done at 120 days in all the sowing times.

\subsection{Data Collection}

Leaf area was measured at 30, 45, 60,75,90 and 105 DAS at time of harvesting for five plants using Portable leaf area meter (ICT International, Cl-202). Leaf area index was find out by using ${ }^{28}$ equation.

Leaf Area Index $($ LAI $)=\frac{\text { Leaf area per plant }}{\text { Land area per plant }}$

At harvesting, the plant height, number of clusters per plant, pod length, pods per cluster and grains per pods of five randomly selected plants from each plot. Grain yield was obtained from the collected pods from each plot. Based on the net plot yield obtained from all the harvested pods, yield per hectare was found. Sub samples of 100 grains were obtained from five plants of each plot randomly chosen. On an electronic balance (KERN, ALJ-310-4N) these samples were weighed. 
SPAD-502 (Spectrum Technologies:2900PDL) used to taken the leaf chlorophyll content at 90 DAS. Photosynthetic rate and transpiration rate data were taken by using infrared gas analyzer [CID Bio-Science, $\mathrm{Cl}-340]$.

\subsection{Statistical Analysis}

Growth, yield and physiological parameters was statistically analyzed by using linear model in R software ${ }^{29}$. The means were compared at $p \leq 0.05$ using adjusted Tukey multiple comparison procedure with "emmeans" package ${ }^{30,31}$.

\section{Results}

\subsection{Pods Plant ${ }^{-1}$ and Pod Length}

The main effect of sowing time and plant spacing was statistically significant at $P<0.05$, however, interaction effect of sowing and plant spacing was non-significant on pods plant $^{-1}$ (Table 1).

Table 1

$P$ value of main and interaction effect of sowing time and plant spacing on growth, yield and physiological parameters of cluster

\begin{tabular}{|c|c|c|c|c|c|c|c|c|c|c|c|c|}
\hline Effect & $\begin{array}{l}\text { Pods } \\
\text { Plant } \\
1\end{array}$ & $\begin{array}{l}\text { Pod } \\
\text { length }\end{array}$ & $\begin{array}{l}\text { Cluster } \\
\text { Plant }^{-} \\
1\end{array}$ & $\begin{array}{l}\text { Plant } \\
\text { height }\end{array}$ & $\begin{array}{l}\text { Pods } \\
\text { cluster } \\
1\end{array}$ & $E$ & $\mathrm{Pn}$ & $\begin{array}{l}\text { Leaf } \\
\text { Area } \\
\text { Index }\end{array}$ & $\begin{array}{l}\text { Chlorophyll } \\
\text { contents }\end{array}$ & $\begin{array}{l}\text { Grain } \\
\text { yield }\end{array}$ & $\begin{array}{l}100- \\
\text { grain } \\
\text { weight }\end{array}$ & $\begin{array}{l}\text { Grains } \\
\text { pod }^{-1}\end{array}$ \\
\hline $\begin{array}{l}\text { Sowing } \\
\text { time (S) }\end{array}$ & $<0.01$ & $<0.01$ & $<0.01$ & $<0.01$ & $<0.01$ & 0.23 & 0.02 & $\begin{array}{l}< \\
0.01\end{array}$ & $<0.01$ & $\begin{array}{l}< \\
0.01\end{array}$ & $<0.01$ & $<0.01$ \\
\hline $\begin{array}{l}\text { Plant } \\
\text { Spacing } \\
(P)\end{array}$ & 0.01 & 0.01 & 0.02 & $<0.01$ & 0.09 & 0.09 & 0.37 & $\begin{array}{l}< \\
0.01\end{array}$ & 0.08 & $\begin{array}{l}< \\
0.01\end{array}$ & $<0.01$ & 0.25 \\
\hline$S \times P$ & 0.29 & 0.77 & 0.84 & $<0.01$ & 0.81 & 0.22 & 0.22 & $<.01$ & 0.16 & $\dot{0} 01$ & 0.36 & 0.59 \\
\hline
\end{tabular}

First June sowing time performed better on pods per plant as compared other sowing times (15th May, 15th June and 1st July) (Table 2). The wider plant spacing $15 \mathrm{~cm}$ showed higher response on pods per plant in all sowing times as compared to 10 and $12 \mathrm{~cm}$. In 15th May, plant spacing $15 \mathrm{~cm}$ showed 30.2 and $12.6 \%$ as compared to 10 and $12 \mathrm{~cm}$ respectively (Table 2; Fig. 2A). In 1 st June, plant spacing $15 \mathrm{~cm}$ showed 26.1 and $37.6 \%$ as compared to 10 and $12 \mathrm{~cm}$ respectively (Table 2). In 15 th June, plant spacing $15 \mathrm{~cm}$ showed 26.6 and $25.4 \%$ as compared to 10 and $12 \mathrm{~cm}$ respectively (Table 2). In 1 st July, planting density $15 \mathrm{~cm}$ showed 27.5 and $37.8 \%$ as compared to 10 and $12 \mathrm{~cm}$ respectively (Table 2 ). The main effect of sowing time and plant spacing was statistically significant at $p<0.05$, however, interaction effect of sowing and plant spacing was non-significant on pod length (Table 1). First June sowing time showed better on pod length as compared to other sowing times (15th May, 15th June and 1st July). The wider plant spacing $15 \mathrm{~cm}$ showed higher response on pod length in all sowing times as compared to 10 and $12 \mathrm{~cm}$ (Fig. 2B). In 15th May, plant spacing $15 \mathrm{~cm}$ showed 10.6 and $4 \%$ as compared to 10 and $12 \mathrm{~cm}$ respectively (Table 2). In $1 \mathrm{st}$ June, plant spacing $15 \mathrm{~cm}$ showed 9.2 and $4.4 \%$ as compared to 10 and $12 \mathrm{~cm}$ respectively (Table 1). In 15th June, plant spacing $15 \mathrm{~cm}$ showed 7.5 and $7.5 \%$ as compared to 10 and $12 \mathrm{~cm}$ respectively (Table 2). In $1 \mathrm{st}$ July, plant spacing $15 \mathrm{~cm}$ showed 2.2 and $2.2 \%$ as compared to 10 and $12 \mathrm{~cm}$ respectively. 
Table 2

Impact of sowing time and plant spacing on pods plant ${ }^{-1}$ and pod length of cluster bean

\begin{tabular}{|c|c|c|c|c|c|c|c|c|}
\hline \multirow{3}{*}{$\begin{array}{l}\text { Plant Spacing } \\
\text { (cm) }\end{array}$} & \multicolumn{4}{|c|}{ Pods plant ${ }^{-1}$} & \multicolumn{4}{|c|}{ Pod length (cm) } \\
\hline & \multicolumn{4}{|c|}{ Sowing times } & \multicolumn{4}{|c|}{ Sowing times } \\
\hline & 15th May & 1st June & 15th June & 1st July & 15th May & 1st June & $\begin{array}{l}\text { 15th } \\
\text { June }\end{array}$ & 1st July \\
\hline 10 & $\begin{array}{l}281.0 \pm \\
11.0 \mathrm{a}\end{array}$ & $\begin{array}{l}371.6 \pm \\
69.2 \mathrm{a}\end{array}$ & $\begin{array}{l}109.6 \pm \\
14.5 \mathrm{a}\end{array}$ & $\begin{array}{l}40.0 \pm \\
3.46 a\end{array}$ & $\begin{array}{l}4.7 .0 \pm \\
0.6 a\end{array}$ & $\begin{array}{l}6.5 \pm \\
0.5 a\end{array}$ & $\begin{array}{l}5.3 \pm \\
0.3 a\end{array}$ & $\begin{array}{l}4.5 \pm \\
0.2 \mathrm{a}\end{array}$ \\
\hline 12 & $\begin{array}{l}325.0 \pm \\
17.0 \mathrm{~b}\end{array}$ & $\begin{array}{l}340.6 \pm \\
123.5 a\end{array}$ & $\begin{array}{l}110.3 \pm \\
15.7 \mathrm{a}\end{array}$ & $\begin{array}{l}37.6 \pm \\
3.79 a\end{array}$ & $\begin{array}{l}5.0 \pm \\
0.7 \mathrm{ab}\end{array}$ & $\begin{array}{l}6.8 \pm \\
0.6 a\end{array}$ & $\begin{array}{l}5.3 \pm \\
0.2 a\end{array}$ & $\begin{array}{l}4.5 \pm \\
0.3 a\end{array}$ \\
\hline 15 & $\begin{array}{l}366.3 \pm \\
14.0 \mathrm{c}\end{array}$ & $\begin{array}{l}468.6 \pm \\
36.9 a\end{array}$ & $\begin{array}{l}138.0 \pm \\
5.2 \mathrm{a}\end{array}$ & $\begin{array}{l}51.0 \pm \\
10.82 a\end{array}$ & $\begin{array}{l}5.2 .0 \pm \\
0.87 \mathrm{~b}\end{array}$ & $\begin{array}{l}7.1 \pm \\
1.01 a\end{array}$ & $\begin{array}{l}5.7 \pm \\
0.3 \mathrm{~b}\end{array}$ & $\begin{array}{l}4.6 \pm \\
0.4 a\end{array}$ \\
\hline
\end{tabular}

The values are the mean and standard deviation of three replications. Within plant spacing the values with same letter (s) are statistically non-significant at $p<0.05$

\subsection{Cluster Plant ${ }^{-1}$}

The main effect of sowing time and plant spacing was statistically significant at $p<0.05$, however, interaction effect of sowing and plant spacing was non-significant on cluster plant ${ }^{-1}$ (Table 1). First June sowing time performed better on clusters plant ${ }^{-1}$ as compared other sowing times (15th May, 15th June and 1st July) (Table 3). The wider plant spacing $15 \mathrm{~cm}$ showed higher response on clusters per plant in all sowing times as compared to 10 and $12 \mathrm{~cm}$ (Fig. 3). In 15th May, plant spacing $15 \mathrm{~cm}$ showed 6.5 and $1.8 \%$ as compared to 10 and $12 \mathrm{~cm}$ respectively (Table 3). In $1 \mathrm{st}$ June, plant spacing $15 \mathrm{~cm}$ showed 6.2 and $2.2 \%$ as compared to 10 and $12 \mathrm{~cm}$ respectively (Table 3 ). In 15th June, plant spacing $15 \mathrm{~cm}$ showed 6.9 and $2 \%$ as compared to 10 and $12 \mathrm{~cm}$ respectively (Table 3). In $1 \mathrm{st}$ July, planting density $15 \mathrm{~cm}$ showed 15.1 and $15.1 \%$ as compared to 10 and $12 \mathrm{~cm}$ respectively (Table 3).

Table 3

Impact of sowing time and plant spacing on cluster plant ${ }^{-1}$ of cluster bean

\begin{tabular}{|lllll|}
\hline Plant Spacing (cm) & \multicolumn{2}{l|}{ Clusters plant $^{-1}$} & \\
& \multicolumn{2}{l}{ Sowing times } \\
& 15th May & 1st June & 15th June & 1st July \\
\hline 10 & $15.3 \pm 0.5 \mathrm{a}$ & $16.67 \pm 1.5 \mathrm{a}$ & $14.3 \pm 0.6 \mathrm{a}$ & $6.67 \pm 0.5 \mathrm{a}$ \\
\hline 12 & $16.0 \pm 10.0 \mathrm{ab}$ & $18.0 \pm 20.0 \mathrm{a}$ & $15.0 \pm 0.01 \mathrm{ab}$ & $6.67 \pm 0.5 \mathrm{a}$ \\
\hline 15 & $16.3 \pm 0.5 \mathrm{~b}$ & $17.6 \pm 2.1 \mathrm{a}$ & $15.3 \pm 0.5 \mathrm{~b}$ & $7.67 \pm 1.5 \mathrm{a}$ \\
\hline
\end{tabular}

The values are the mean and standard deviation of three replications. Within plant spacing the values with same letter (s) are statistically non-significant at $p<0.05$

\subsection{Plant Height and Pods Cluster $^{-1}$}

The main and interaction effect of sowing time and plant spacing were significant at $\mathrm{P}<0.05$ on plant height (Table 1). First June sowing time performed better on plant height as compared other sowing times (15th May, 15th June and 1st July) (Table 4). The wider plant spacing $15 \mathrm{~cm}$ showed higher response on plant height in all sowing times as compared to 10 and $12 \mathrm{~cm}$ (Fig. 4A). In 15th May, plant spacing $15 \mathrm{~cm}$ showed 5.6 and $2.7 \%$ as compared to 10 and $12 \mathrm{~cm}$ respectively (Table 4). In $1 \mathrm{st}$ June, plant spacing $15 \mathrm{~cm}$ showed 10.6 and $3.9 \%$ as compared to 10 and $12 \mathrm{~cm}$ respectively (Table 4). In 15th June, plant spacing $15 \mathrm{~cm}$ showed 3.6 and $3.6 \%$ as compared to 10 and $12 \mathrm{~cm}$ respectively (Table 4). In 1 st July, planting density $15 \mathrm{~cm}$ showed 3.4 and $0.8 \%$ as compared to 10 and $12 \mathrm{~cm}$ respectively (Table 4). The main effect of sowing time and plant spacing was statistically significant at $P<0.05$, however, interaction effect of sowing and plant spacing was non-significant on pods cluster ${ }^{-1}$ (Table 1). First June sowing time showed better effect on pods per cluster as compared to other sowing times (15th May, 15th June and 1st July). The 
wider plant spacing $15 \mathrm{~cm}$ showed higher response on pods per cluster in all sowing times as compared to 10 and $12 \mathrm{~cm}$ (Fig. 4B). In 15th May, plant spacing $15 \mathrm{~cm}$ showed 9.5 and $4.5 \%$ as compared to 10 and $12 \mathrm{~cm}$ respectively (Table 4). In $1 \mathrm{st}$ June, plant spacing $15 \mathrm{~cm}$ showed 4.5 and $0 \%$ as compared to 10 and $12 \mathrm{~cm}$ respectively (Table 4). In 15th June, plant spacing $15 \mathrm{~cm}$ showed 18.4 and $23.2 \%$ as compared to 10 and $12 \mathrm{~cm}$ respectively (Table 4). In $1 \mathrm{st}$ July, plant spacing $15 \mathrm{~cm}$ showed 11.1 and $19.1 \%$ as compared to 10 and $12 \mathrm{~cm}$ respectively.

Table 4

Impact of sowing time and plant spacing on plant height and pod cluster ${ }^{-1}$ of cluster bean

\begin{tabular}{|c|c|c|c|c|c|c|c|c|}
\hline \multirow{3}{*}{$\begin{array}{l}\text { Plant Spacing } \\
\text { (cm) }\end{array}$} & \multicolumn{4}{|c|}{ Plant height $(\mathrm{cm})$} & \multicolumn{4}{|c|}{ Pods cluster ${ }^{-1}$} \\
\hline & \multicolumn{4}{|c|}{ Sowing times } & \multicolumn{4}{|c|}{ Sowing times } \\
\hline & 15th May & 1st June & 15th June & 1st July & 15th May & 1st June & $\begin{array}{l}\text { 15th } \\
\text { June }\end{array}$ & 1st July \\
\hline 10 & $142.3 \pm 7.5 \mathrm{a}$ & $\begin{array}{l}142.6 \pm \\
8.0 a\end{array}$ & $\begin{array}{l}137.6 \pm \\
4.73 a\end{array}$ & $\begin{array}{l}116.3 \pm \\
6.1 \mathrm{a}\end{array}$ & $\begin{array}{l}21.0 \pm \\
1.7 a\end{array}$ & $\begin{array}{l}22.3 \pm \\
2.3 a\end{array}$ & $\begin{array}{l}7.67 \pm \\
1.1 \mathrm{a}\end{array}$ & $\begin{array}{l}6.0 \pm \\
0.0 \mathrm{ab}\end{array}$ \\
\hline 12 & $\begin{array}{l}146.0 \pm \\
60.0 \mathrm{ab}\end{array}$ & $\begin{array}{l}152.3 \pm \\
5.1 \mathrm{~b}\end{array}$ & $\begin{array}{l}137.0 \pm \\
8.19 a\end{array}$ & $\begin{array}{l}119.3 \pm \\
4.5 \mathrm{a}\end{array}$ & $\begin{array}{l}22.3 \pm \\
2.5 \mathrm{ab}\end{array}$ & $\begin{array}{l}23.0 \pm \\
2.0 a\end{array}$ & $\begin{array}{l}7.33 \pm \\
0.6 a\end{array}$ & $\begin{array}{l}5.6 \pm \\
0.5 a\end{array}$ \\
\hline 15 & $150.6 \pm 8.9 b$ & $\begin{array}{l}157.6 \pm \\
4.0 \mathrm{~b}\end{array}$ & $\begin{array}{l}142.3 \pm \\
3.06 \mathrm{a}\end{array}$ & $\begin{array}{l}120.0 \pm \\
8.5 a\end{array}$ & $\begin{array}{l}23.0 \pm \\
02.0 \mathrm{~b}\end{array}$ & $\begin{array}{l}23.0 \pm \\
2.6 a\end{array}$ & $9 \pm 0.0 \mathrm{a}$ & $\begin{array}{l}6.6 \pm \\
0.5 \mathrm{~b}\end{array}$ \\
\hline
\end{tabular}

The values are the mean and standard deviation of three replications. Within plant spacing the values with same letter (s) are statistically non- significant at $p<0.05$

\subsection{Grain Yield, 100-Grain Weight, and Grains $\operatorname{Pod}^{-1}$}

The main and interaction effect of sowing time and plant spacing were significant at $p<0.05$ on grain yield (Table 1). First June sowing time performed better on grain yield as compared other sowing times (15th May, 15th June and 1st July) (Figs. 5 and 6A). The wider plant spacing $15 \mathrm{~cm}$ showed higher response on grain yield in all sowing times as compared to 10 and $12 \mathrm{~cm}$. In $15 \mathrm{th}$ May, plant spacing $15 \mathrm{~cm}$ showed 25.6 and $4.5 \%$ as compared to 10 and $12 \mathrm{~cm}$ respectively (Fig. 5). In $1 \mathrm{st}$ June, plant spacing $15 \mathrm{~cm}$ showed 20.5 and $7.3 \%$ as compared to 10 and $12 \mathrm{~cm}$ respectively (Fig. 5). In 15th June, plant spacing $15 \mathrm{~cm}$ showed 35.0 and $5.3 \%$ as compared to 10 and $12 \mathrm{~cm}$ respectively (Fig. 5). In 1st July, planting density $15 \mathrm{~cm}$ showed 19.1 and $10.5 \%$ as compared to 10 and $12 \mathrm{~cm}$ respectively (Fig. 5). The main effect of sowing time and plant spacing was statistically significant at $p$ $<0.05$, however, interaction effect of sowing and plant spacing was non-significant on 100-grain weight (Table 1). First June sowing time performed better on 100-grain weight as compared to other sowing times (15th May, 15th June and 1st July). The wider plant spacing $15 \mathrm{~cm}$ showed higher response on 100-grain weight in all sowing times as compared to 10 and $12 \mathrm{~cm}$. In 15 th May, plant spacing $15 \mathrm{~cm}$ showed 20.5 and $13.8 \%$ as compared to 10 and $12 \mathrm{~cm}$ respectively (Figs. 5 and $6 \mathrm{~B}$ ). In 1 st June, plant spacing $15 \mathrm{~cm}$ showed 19.1 and $9.8 \%$ as compared to 10 and $12 \mathrm{~cm}$ respectively (Fig. 5). In 15th June, plant spacing $15 \mathrm{~cm}$ showed 0 and $2.7 \%$ as compared to 10 and $12 \mathrm{~cm}$ respectively (Fig. 5). In 1 st July, plant spacing $15 \mathrm{~cm}$ showed 29.4 and $15.7 \%$ as compared to 10 and $12 \mathrm{~cm}$ respectively). The main effect of sowing time and plant spacing was statistically significant at $P<0.05$, however, interaction effect of sowing and plant spacing was non-significant on grains $\operatorname{pod}^{-1}$ (Table 1). First June sowing time performed better on grains pod $^{-1}$ as compared to other sowing times (15th May, 15th June and 1st July) (Fig. 5). The wider plant spacing $15 \mathrm{~cm}$ showed higher response on grains per pod in all sowing times as compared to 10 and $12 \mathrm{~cm}$. In 15th May, plant spacing $15 \mathrm{~cm}$ showed 15.7 and $13.6 \%$ as compared to 10 and $12 \mathrm{~cm}$ respectively (Fig. 5). In 1 st June, plant spacing $15 \mathrm{~cm}$ showed 3.2 and $3.2 \%$ as compared to 10 and $12 \mathrm{~cm}$ respectively (Figs. 5 and 6C). In 15th June, plant spacing $15 \mathrm{~cm}$ showed 10.6 and $4.2 \%$ as compared to 10 and $12 \mathrm{~cm}$ respectively (Fig. 5). In $1 \mathrm{st} \mathrm{July,} \mathrm{plant} \mathrm{spacing} 15 \mathrm{~cm}$ showed 6.0 and $6.0 \%$ as compared to 10 and $12 \mathrm{~cm}$ respectively.

\subsection{Transpiration and Photosynthetic Rates}

The main and interaction effect of sowing time and plant spacing was statistically non-significant at $\mathrm{p}<0.01$ on transpiration rate (Table 1). The 15th May sowing time performed better on transpiration rate as compared other sowing times (15th June, 15th June and 1st July) (Table 5). The wider plant spacing $15 \mathrm{~cm}$ showed higher response on transpiration rate in all sowing times as compared to 10 and $12 \mathrm{~cm}$ (Fig. 7A). In 15th May, plant spacing $15 \mathrm{~cm}$ showed 16.5 and $101.1 \%$ as compared to 10 and $12 \mathrm{~cm}$ 
respectively (Table 5). In 1 st June, plant spacing $15 \mathrm{~cm}$ showed 22.7 and $83.0 \%$ as compared to 10 and $12 \mathrm{~cm}$ respectively (Table 5). In 15th June, plant spacing $15 \mathrm{~cm}$ showed 16.6 and $62.9 \%$ as compared to 10 and $12 \mathrm{~cm}$ respectively (Table 5). In $1 \mathrm{st}$ July, planting density $12 \mathrm{~cm}$ showed 38.2 and $81.4 \%$ as compared to 10 and $15 \mathrm{~cm}$ respectively (Table 5). The main and interaction effect of sowing time and plant spacing was statistically non-significant at $p<0.01$ on photosynthetic rate (Table 1 ). The 15th May sowing time performed better on photosynthetic rate as compared to other sowing times (1st June, 15th June and $1 \mathrm{st}$ July). The lower plant spacing $15 \mathrm{~cm}$ showed higher response on photosynthetic rate in all sowing times as compared to 10 and $12 \mathrm{~cm}$ (Fig. 7B). In 15th May, plant spacing $10 \mathrm{~cm}$ showed 53.2 and $40.4 \%$ as compared to 12 and $15 \mathrm{~cm}$ respectively (Table 5). In 1st June, plant spacing $15 \mathrm{~cm}$ showed 67.9 and $36.9 \%$ as compared to 10 and $12 \mathrm{~cm}$ respectively (Table 5). In 15th June, plant spacing $12 \mathrm{~cm}$ showed 7.9 and $10.6 \%$ as compared to 10 and $15 \mathrm{~cm}$ respectively. In $1 \mathrm{st}$ July, plant spacing $12 \mathrm{~cm}$ showed 77.3 and $81.8 \%$ as compared to 10 and $12 \mathrm{~cm}$ respectively (Table 5).

Table 5

Impact of sowing time and plant spacing on transpiration and photosynthetic rates of cluster bean

\begin{tabular}{|c|c|c|c|c|c|c|c|c|}
\hline \multirow{3}{*}{$\begin{array}{l}\text { Plant Spacing } \\
\text { (cm) }\end{array}$} & \multicolumn{4}{|c|}{ Transpiration rate } & \multicolumn{4}{|c|}{ Photosynthetic rate } \\
\hline & \multicolumn{4}{|c|}{ Sowing times } & \multicolumn{4}{|c|}{ Sowing times } \\
\hline & $\begin{array}{l}\text { 15th } \\
\text { May }\end{array}$ & $\begin{array}{l}\text { 1st } \\
\text { June }\end{array}$ & $\begin{array}{l}\text { 15th } \\
\text { June }\end{array}$ & 1st July & 15th May & 1st June & 15th June & 1st July \\
\hline 10 & $\begin{array}{l}4.5 \pm \\
1.5 \mathrm{ab}\end{array}$ & $\begin{array}{l}3.3 \pm \\
1.9 a\end{array}$ & $\begin{array}{l}4.6 \pm \\
1.8 a\end{array}$ & $\begin{array}{l}2.4 \pm \\
0.15 a\end{array}$ & $\begin{array}{l}492.8 \pm \\
78.33 a\end{array}$ & $\begin{array}{l}203.2 \pm \\
15.6 a\end{array}$ & $\begin{array}{l}245.2 \pm \\
3.0 a\end{array}$ & $\begin{array}{l}237.3 \pm \\
20.8 a\end{array}$ \\
\hline 12 & $\begin{array}{l}2.6 \pm \\
1.6 a\end{array}$ & $\begin{array}{l}2.2 \pm \\
0.6 \mathrm{a}\end{array}$ & $\begin{array}{l}3.2 \pm \\
1.2 \mathrm{a}\end{array}$ & $\begin{array}{l}4.4 \pm \\
1.12 b\end{array}$ & $\begin{array}{l}451.1 \pm \\
128.2 \mathrm{a}\end{array}$ & $\begin{array}{l}249.9 \pm \\
20.2 a\end{array}$ & $\begin{array}{l}271.6 \pm \\
3.11 a\end{array}$ & $\begin{array}{l}431.7 \pm \\
251.2 \mathrm{a}\end{array}$ \\
\hline 15 & $\begin{array}{l}5.3 \pm \\
1.6 \mathrm{~b}\end{array}$ & $\begin{array}{l}4.1 \pm \\
1.9 a\end{array}$ & $\begin{array}{l}5.3 \pm \\
1.8 a\end{array}$ & $\begin{array}{l}3.2 \pm \\
0.15 a b\end{array}$ & $\begin{array}{l}321.6 \pm \\
124.2 \mathrm{a}\end{array}$ & $\begin{array}{l}341.9 \pm \\
246.4 a\end{array}$ & $\begin{array}{l}251.2 \pm \\
3.0 a\end{array}$ & $\begin{array}{l}243.4 \pm \\
20.8 \mathrm{a}\end{array}$ \\
\hline
\end{tabular}

The values are the mean and standard deviation of three replications. Within plant spacing the values with same letter (s) are statistically non-significant at $p<0.05$

\subsection{Leaf Area Index and Chlorophyll Contents}

The main and interaction effect of sowing time and plant spacing were statistically significant at $p<0.05$ on leaf area index. First June sowing time performed better on leaf area index as compared other sowing times (15th May, 15th June and 1st July) (Table 6). The wider plant spacing $15 \mathrm{~cm}$ showed higher response on leaf area index in all sowing times as compared to 10 and $12 \mathrm{~cm}$ (Fig. 8A). In 15th May, plant spacing $15 \mathrm{~cm}$ showed 25.6 and $4.5 \%$ as compared to 10 and $12 \mathrm{~cm}$ respectively (Table 6). In 1st June, plant spacing $15 \mathrm{~cm}$ showed 0 and $5.5 \%$ as compared to 10 and $12 \mathrm{~cm}$ respectively (Table 6). In 15th June, plant spacing $15 \mathrm{~cm}$ showed 14.2 and $6.6 \%$ as compared to 10 and $12 \mathrm{~cm}$ respectively. In $1 \mathrm{st}$ July, planting density $15 \mathrm{~cm}$ showed 3.0 and $36 \%$ as compared to 10 and $12 \mathrm{~cm}$ respectively (Table 7). The main effect of sowing time was statistically significant at $P<0.05$, however, the main effect of plant spacing and interaction effect of sowing time and plant spacing was non-significant on chlorophyll contents. First June sowing time performed better on chlorophyll contents as compared to other sowing times (15th May, 15th June and 1st July). The wider plant spacing $15 \mathrm{~cm}$ showed higher response on chlorophyll contents in all sowing times as compared to 10 and $12 \mathrm{~cm}$ (Fig. 8B). In 15th May, plant spacing $15 \mathrm{~cm}$ showed 0.1 and $3.7 \%$ as compared to 10 and $12 \mathrm{~cm}$ respectively (Table 6). In 1st June, plant spacing $15 \mathrm{~cm}$ showed 29.2 and $9.0 \%$ as compared to 10 and $12 \mathrm{~cm}$ respectively (Table 6). In 15th June, plant spacing $15 \mathrm{~cm}$ showed 7.8 and $9.52 \%$ as compared to 10 and $12 \mathrm{~cm}$ respectively. In $1 \mathrm{st}$ July, plant spacing $15 \mathrm{~cm}$ showed 3.4 and $1.7 \%$ as compared to 10 and $12 \mathrm{~cm}$ respectively. Pearson correlation (Fig. 9) and chord diagram also justified the significance of sowing time (Fig. 10A) and plant spacing (Fig. 10B) for the improvement in growth and yield attributes of cluster bean. 
Table 6

Impact of sowing time and plant spacing on leaf area index and chlorophyll contents of cluster bean

\begin{tabular}{|c|c|c|c|c|c|c|c|c|}
\hline \multirow{3}{*}{$\begin{array}{l}\text { Plant Spacing } \\
\text { (cm) }\end{array}$} & \multicolumn{4}{|c|}{ Leaf area index } & \multicolumn{4}{|c|}{ Chlorophyll contents } \\
\hline & \multicolumn{4}{|c|}{ Sowing times } & \multicolumn{4}{|c|}{ Sowing times } \\
\hline & $\begin{array}{l}\text { 15th } \\
\text { May }\end{array}$ & 1st June & 15th June & 1st July & 15th May & 1st June & 15th June & 1st July \\
\hline
\end{tabular}

\begin{tabular}{|c|c|c|c|c|c|c|c|c|}
\hline 10 & $\begin{array}{l}0.3 \pm \\
0.06 a\end{array}$ & $\begin{array}{l}0.38 \pm \\
0.03 \mathrm{~b}\end{array}$ & $\begin{array}{l}0.28 \pm \\
0.05 a\end{array}$ & $\begin{array}{l}0.33 \pm \\
0.04 \mathrm{~b}\end{array}$ & $62.9 \pm 5.85 a$ & $\begin{array}{l}65.4 \pm \\
7.7 a\end{array}$ & $\begin{array}{l}64.97 \pm \\
7.5 a\end{array}$ & $\begin{array}{l}38.02 \pm \\
7.2 \mathrm{a}\end{array}$ \\
\hline 12 & $\begin{array}{l}0.3 \pm \\
0.05 a\end{array}$ & $\begin{array}{l}0.36 \pm \\
0.04 a\end{array}$ & $\begin{array}{l}0.3 \pm \\
0.05 \mathrm{ab}\end{array}$ & $\begin{array}{l}0.25 \pm \\
0.04 a\end{array}$ & $\begin{array}{l}60.78 \pm \\
8.48 a\end{array}$ & $\begin{array}{l}77.3 \pm \\
8.2 b\end{array}$ & $\begin{array}{l}63.77 \pm \\
12.3 a\end{array}$ & $\begin{array}{l}40.81 \pm \\
7.1 \mathrm{a}\end{array}$ \\
\hline 15 & $\begin{array}{l}0.4 \pm \\
0.04 a\end{array}$ & $\begin{array}{l}0.39 \pm \\
0.04 \mathrm{~b}\end{array}$ & $\begin{array}{l}0.32 \pm \\
0.05 b\end{array}$ & $\begin{array}{l}0.34 \pm \\
0.04 \mathrm{~b}\end{array}$ & $\begin{array}{l}62.38 \pm \\
11.34 a\end{array}$ & $\begin{array}{l}84.1 \pm \\
5.9 \mathrm{c}\end{array}$ & $\begin{array}{l}69.25 \pm \\
5.1 \mathrm{a}\end{array}$ & $\begin{array}{l}39.32 \pm \\
1.0 a\end{array}$ \\
\hline
\end{tabular}

The values are the mean and standard deviation of three replications. Within plant spacing the values with same letter (s) are statistically non-significant at $p<0.05$.

\section{Discussion}

The present study was carried out to evaluate the effects of different sowing times (15th May, 1st June, 15th June and 1st July) and planting spacing $(10,12$ and $15 \mathrm{~cm})$ on cluster bean production in Multan, Pakistan. Results revealed that cluster bean sowing at 1st June showed higher values of growth, yield, and physiological parameters as compared to the other sowing times (15th May, 15th June and 1st July). In addition, wider plant spacing $(15 \mathrm{~cm})$ showed better response as compared to narrow plant spacing (10 and $12 \mathrm{~cm}$ ).

The sowing time 1st June with planting spacing $15 \mathrm{~cm}$ significantly increased the plant height, chlorophyll contents, clusters plant ${ }^{1}$, pods plant ${ }^{-1}$, pods per cluster, leaf area index, transpiration rate, photosynthetic rate, grains per pod, pod length, 100-grain weight and grain yield. Adequate temperature and supply of nutrients increased growth, physiological and yield attributes of cluster bean in current study might be the possible reasons for increase of cluster bean productivity. These findings are in line with the literature. In study of Nikam et al. ${ }^{32}$ cluster bean showed maximum plant height when cluster bean was sown in late (1st February) as compared to other early sowing times (1st January and 15th January).

The cluster bean sown in February obtained the longer duration of growth period with suitable climatic conditions as compared to other sowing times. In another study conducted by Meena et al. ${ }^{12}$ early sowing of cluster bean increases the crop growth rate and yield parameters as compared to late sowing. Meen et al. ${ }^{12}$ found that sowing time (1st July) obtained higher cluster bean yield as

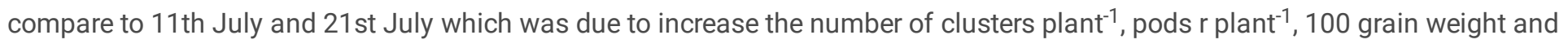
optimum environmental conditions during the crop period ${ }^{22}$. Ayoub and Hussein ${ }^{34}$ reported that unfavorable environmental conditions due to improper sowing time have great influence on cluster bean yield attributes like clusters per plant ${ }^{-1}$, pods cluster ${ }^{-1}$, and clusters pod $^{-1}$.

Dhedhi et al. ${ }^{22}$ reported adverse environmental effects on cluster bean yield due to late sowing. The reduction in photosynthetic rate in study of Dhedhi et al. ${ }^{22}$ was found the main reason behind low yield of cluster bean. In other study, James et al. ${ }^{35}$ found that early sowing system combined with slower developing wheat genotypes could exposed to longer season and $0.54 \mathrm{t} \mathrm{ha-1}$ increased in yield is possible under reduced rainfall and increasing temperature regimes. Early sowing also allows deeper root growth, more access to water and less loss of water through evapotranspiration ${ }^{35}$. Therefore, management of sowing time is highly important under changing climatic conditions to provide plants optimal environmental conditions to flourish up to its maximum pick in respect of growth, physiological and yield development. 
Zimmermann et al. ${ }^{11}$ studied a crop, economic and environmental model for six important crops, for 27 countries of the European Union (EU27) to assess climate change impact to 2050. Zimmermann et al. ${ }^{11}$ found that sowing times and thermal time requirement have great impact on crop yields, production, land use and environment quality. The sowing time and selection of appropriate cultivars proved helpful to optimize yields and yield changes as compared to other management practices under changing climate scenario.

The wider plant spacing $(15 \mathrm{~cm})$ showed better effect on growth, yield, and physiological parameters of cluster bean in current study as compared to 10 and $12 \mathrm{~cm}$. This might be due to less competition between plants for space, nutrients, and light. The plants might be got suitable space for the extension of roots and uptake of nutrients from large area as compared to 10 and $12 \mathrm{~cm}$ plant spacing plants. These findings are in line with the studies reported in literature. In study of Nandini et al. ${ }^{36}$, higher plant height and number of leaves plant ${ }^{-1}$ were recorded with wider planting density $(45 \times 15 \mathrm{~cm})$ as compared to lower planting density $(30 \times 15 \mathrm{~cm} \text { and } 45 \times 10 \mathrm{~cm})^{37}$.

\section{Conclusions}

The $1^{\text {st }}$ June sowing time performed better as compared to other sowing time $15^{\text {th }}$ May, $15^{\text {th }}$ June, and $1^{\text {st }}$ July while plant spacing $15 \mathrm{~cm}$ performed best as 10 and $12 \mathrm{~cm}$ spacing. This might be due to prevailing suitable environmental conditions when the crop was sown at $15^{\text {th }}$ June. Therefore, the combination of $1^{\text {st }}$ June sowing time with $15 \mathrm{~cm}$ plant space could be recommend for better growth and yield of cluster bean productivity under current climatic conditions in Multan, Pakistan, however, long-term studies are suggested with different ecological zones to revalidate the finding of this study.

\section{Declarations}

Author Contributions: Conceptualization, I.H.; M.A.; S.A.; O.F.; methodology, I.H.; M.A.; K.S.; validation, M.A.; formal analysis, I.H.; M.A.; investigation, I.H.; M.A.; resources, I.H.; M.A.; data curation, I.H.; M.A.; K.S.; writing-original draft preparation, K.S.; S.I.; F.N.; L.H.A.; R.D.; A.M.; A.G.; writing-review and editing, M.M.I.; S.F.; S.D.; S.T.; A.G.; A.M.; S.A.; O.F.; supervision, M.A.; funding acquisition, S.D.; R.D.; S.F.; A.G.; A.M.;

Funding: Not applicable

Institutional Review Board Statement: Not applicable

Informed Consent Statement: Not applicable

Data Availability Statement: Not applicable

Acknowledgments: Not applicable

Conflicts of Interest: The authors declare no conflict of interest

\section{References}

1. Ashraf, M. \& Iram, A. Drought stress induced changes in some organic substances in nodules and other plant parts of two potential legumes differing in salt tolerance. Flora Morphol. Distrib. Funct. Ecol. Plants. 200, 535-546 (2005).

2. Punia, A., Yadav, R., Arora, P. \& Chaudhury, A. Molecular and morphophysiological characterization of superior cluster bean (Cymopsis tetragonoloba) varieties. J. Crop Sci. Biotechnol. 3, 143-148 (2009).

3. Sabahelkheir, M. K., Abdalla, A. H. \& Nouri, S. H. Quality assessment of guar gum (Endosperm) of guar (Cyamopsis tetragonoloba). ISCA J. Biol. Sci. 1, 67-70 (2012).

4. Srivastava, S. K. \& Ramani, R. Anees \& Promise of Guar Meal.Sci. Report.38-39(2011).

5. Rai, P. S. \& Dharmatti, P. Genetic divergence studies in cluster bean (Cyamopsis tetragonoloba L). J. Sci. Front. Res. Agric. 13, 1-5 (2013). 
6. Kumar, D. \& Rodge, A. Status, scope and strategies of arid legumes research in India-A review. J. Food Legum. 25, 255-272 (2012).

7. Kumar, M. N. \& Ram, A. Tree age affects postharvest attributes and mineral content in amrapali mango (Mangifera indica) fruits. Hortic. Plant J. 4, 55-61 (2018).

8. Punia, A., Yadav, R., Arora, P. \& Chaudhury, A. Molecular and morphophysiological characterization of superior cluster bean (Cymopsis tetragonoloba) varieties. J. Crop Sci. Biotechnol. 12, 143-148 (2009).

9. Ayaz, S., McKenzie, B. A., Hill, G. D. \& McNeil, D. L. Variability in yield of four grain legume species in a subhumid temperate environment. II. Yield components. J. Agric. Sci. 142, 21-28 (2004).

10. Ali, Z., Zahul, S., Hussain, M. Z., ul \& Bashu, M. Sowing dates effects on growth, development and yield of guar (Cyamopsis tetragonoloba L.) under rainfed conditions of pothowar region. J. Agric Res. 42, 33-40 (2004).

11. Zimmermann, A. et al. Climate change impacts on crop yields, land use and environment in response to crop sowing dates and thermal time requirements. Agric. Syst. 157, 81-92 (2017).

12. Meena, R., Yadav, R. \& Meena, V. Respose of groundnut (Arachis hyogaea L.) varieties to sowing dates and NP fertilizers under western dry zone of India. 43,169-173(2014).

13. Meena, H. N. \& Meena, R. S. Role of bio-regulators in clusterbean (Cyamopsis tetragonoloba L.) productivity. Ann. Agri Bio Res. 20, 37-39 (2015).

14. Hussain, A., Khalil, S. K., Khan, S. \& Khan, H. Effect of sowing time and variety on grain yield of mungbean. Sarhad J. Agric. 20, 481-484 (2004).

15. Gresta, F. et al. Effects of sowing times on seed yield, protein and galactomannans content of four varieties of guar (Cyamopsis tetragonoloba L.) in a Mediterranean environment. Ind. Crops Prod. 41, 46-52 (2013).

16. Tripp, L. D., Lovelace, D. A. \& Boring, E. Keys to profitable guar production. Texas Agric. Exp. Stn. Bull.7-11(2011).

17. Sudarma, K., Aini, N. \& Wicaksosno, K. P. Improving of kidney bean production by plant spacing in two different altitudes at south central timor regency, Indonesia. Online J. Biol. Sci. 15, 268 (2015).

18. Acikgoz, E. et al. Forage soybean production for seed in mediterranean environments. F. Crop. Res. 110, $213-218$ (2009).

19. Blumenthal, M., Quach, J. V. P. \& Searle, P. G. E. Effect of soybean population density on soybean yield, nitrogen accumulation and residual nitrogen. Aust. J. Exp. Agric. 28, 99-106 (2005).

20. Ball, R. A., Purcell, L. C. \& Vories, E. D. Short-season soybean yield compensation in response to population and water regime. Crop Sci. 40, 1070-1078 (2000).

21. Choy, S., Prasad, K. M. N., Wu, T. Y. \& Ramanan, R. N. A review on common vegetables and legumes as promising plant-based natural coagulants in water clarification. Int. J. Environ. Sci. Technol. 12, 367-390 (2015).

22. Dhedhi, K. K., Chaudhari, N. N., Juneja, R. P. \& Sorathiya, J. S. Effect of date of sowing and crop geometry on growth and production potential of cluster bean under rainfed condition of Gujarat. Int. J. Bio-resource Stress Manag. 7, 851-854 (2016).

23. McLean, E. O. Soil pH and lime requirement. Methods soil Anal. Part 2 Chem. Microbiol. Prop. 9, 199-224 (1982).

24. Nelson, D. W., Sommers, L. E., Total \& Carbon Organic Carbon, and Organic Matter. in Methods of soil analysis: Part 2 chemical and microbiological properties (ed. Page, A. L.) 539-579(merican Society of Agronomy, Crop Science Society of America, and Soil Science Society of America, 1982).

25. Rhoades, J. D. et al. Electrical Conductivity and Total Dissolved Solids. in Methods of Soil Analysis, Part 3, Chemical Methods (eds. D.L. Sparks)vol. 5 417-435 (Soil Science Society of America, 1996).

26. Pratt, P. F. \& Potassium in Methods of Soil Analysis: Part 2 Chemical and Microbiological Properties, 9.2 (ed. Norman, A. G.) 1022-1030 (John Wiley \& Sons, Ltd, 1965). doi:10.2134/agronmonogr9.2.c20.

27. Kuo, S. et al. in Methods of Soil Analysis Part 3: Chemical Methods (eds. Sparks, D. L. )869-919(John Wiley \& Sons, Ltd, 1996). doi:10.2136/sssabookser5.3.c32.

28. Watson, D. J. The Physiological Basis of Variation in Yield. Adv. Agron. 4, 101-145 (1952).

29. R_Core_Team., R. A language and environment for statistical computing. R Foundation for Statistical Computing, Vienna, Austria. (2020).

30. Lenth, R. \& Emmeans Estimated marginal means, aka least-squares means. R Packag.(2017).

Page $11 / 22$ 
31. Steel, R. G., Torrie, J. H. \& Dickey, D. A. Principles and Procedures of Statistics: A Biometrical Approach(McGraw Hill Book International Co., 1997).

32. Nikam, C., Nagre, P. K. \& Gawande, S. Effect of different dates of sowing and nitrogen levels on growth, seed yield and quality of gum cluster bean. Int. J. Curr. Microbiol. Appl. Sci. 204-2049 https://doi.org/10.18805/ag.D-4715 (2018).

33. Meena, V. K., Kaushik, M. K., Meena, R. S., Meena, V. S. \& Meena, B. P. Effect of growth regulators on clusterbean (Cyamopsistetra gonoloba (L.) growth under Aravali hills improvement in Rajasthan. The bioscan. 9, 547-550 (2014).

34. Ayoub, E. Z. \& Hussein, A. M. Effects of sowing date and plant population on snap bean (Phaseolus vulgaris L.) growth and pod yield in Khartoum State. Univers. J. Agric. Res. 3, 115-118 (2014).

35. Hunt, J. R. et al. Early sowing systems can boost Australian wheat yields despite recent climate change. Nat. Clim. Chang. 9, https://doi.org/10.1038/s41558-019-0417-9 Early (2019).

36. Nandini, K. M., Sridhara, S., Hivanand, P. \& Kiran, K. Effect of planting density and different genotypes on growth, yield and quality of guar. Int. J. Pure Appl. Biosci. 5, 320-328 (2017).

37. Masa, M., Tana, T. \& Ahmad, A. Effect of plant spacing on yield and yield related traits of common Bbean (Phaseolus vulgaris L.) varieties at Areka, Southern Ethiopia. J. Plant Biol. Soil Heal. 4, 1-13 (2017).

\section{Figures}



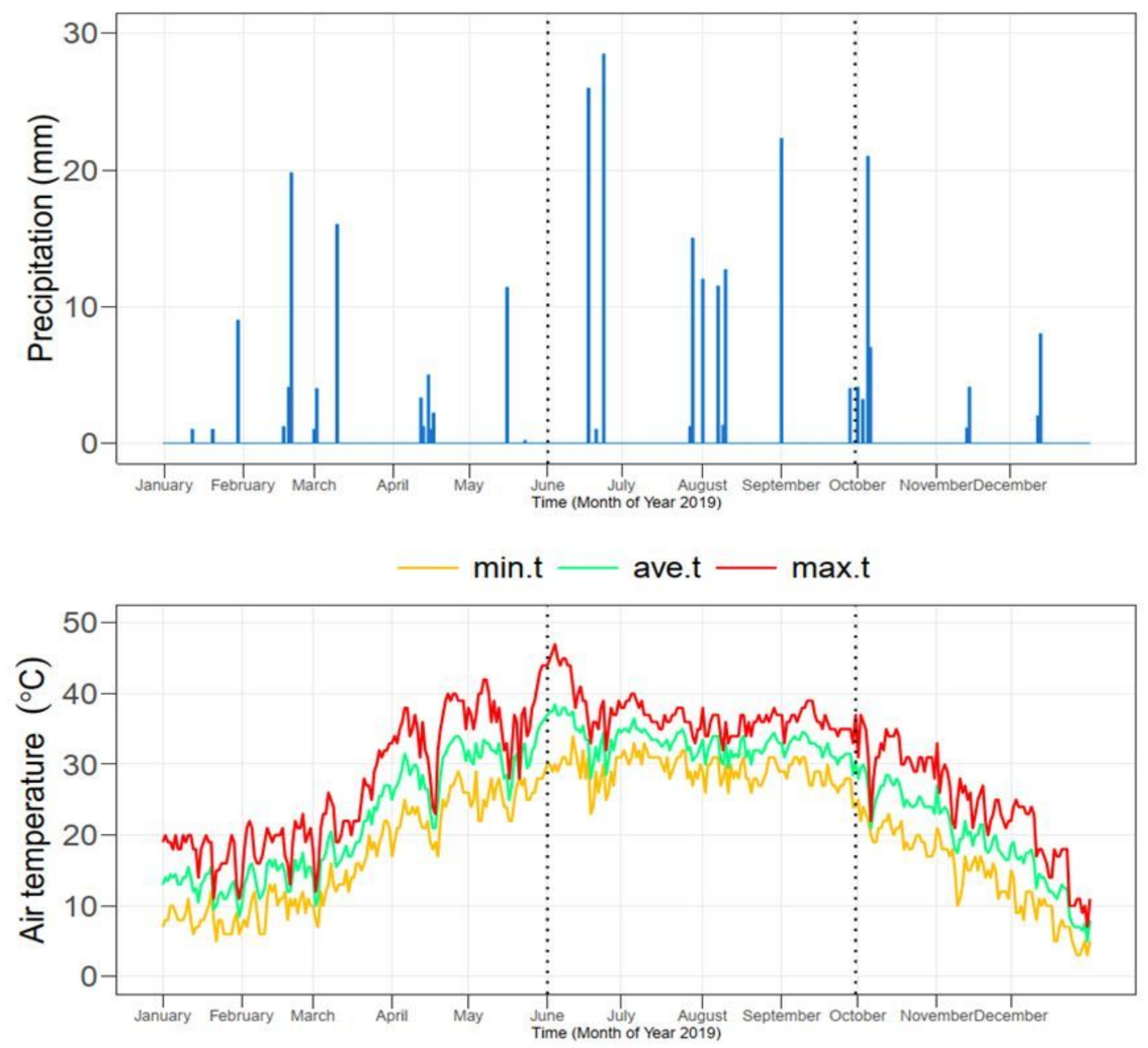

Figure 1

The daily minimum, maximum and average temperature and rainfall in Multan, Pakistan during the year 2019. The dotted lines are showing the duration of cluster bean crop. 

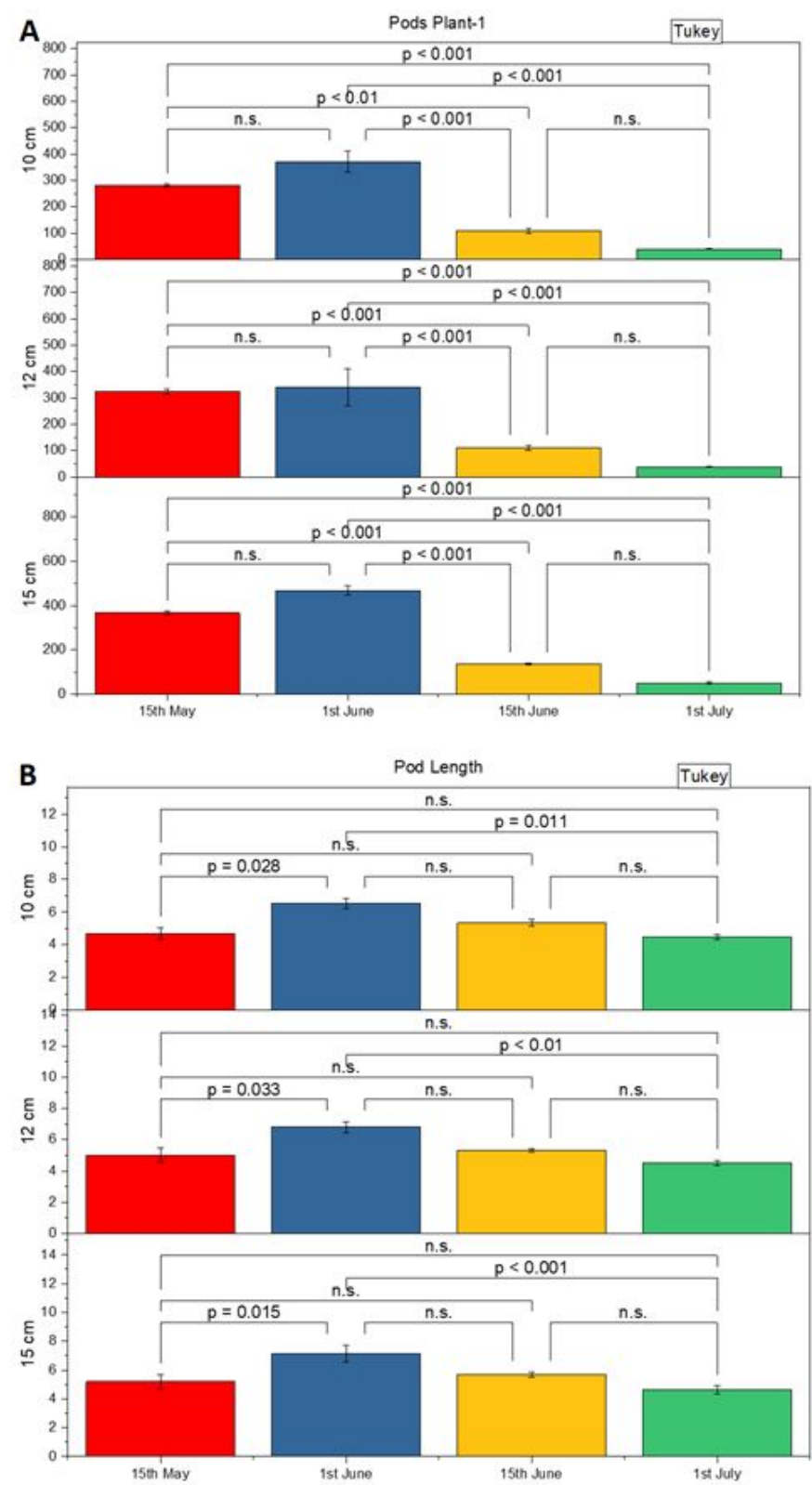

Figure 2

Impact of sowing times and planting spacing on pod plant-1 (A) and pod length (B) of cluster bean. The values are the mean of three replication. The error bars represent the standard error $(n=3)$. Within sowing time, the values are $p$ values computed by tukey test at $p<0.05$. 


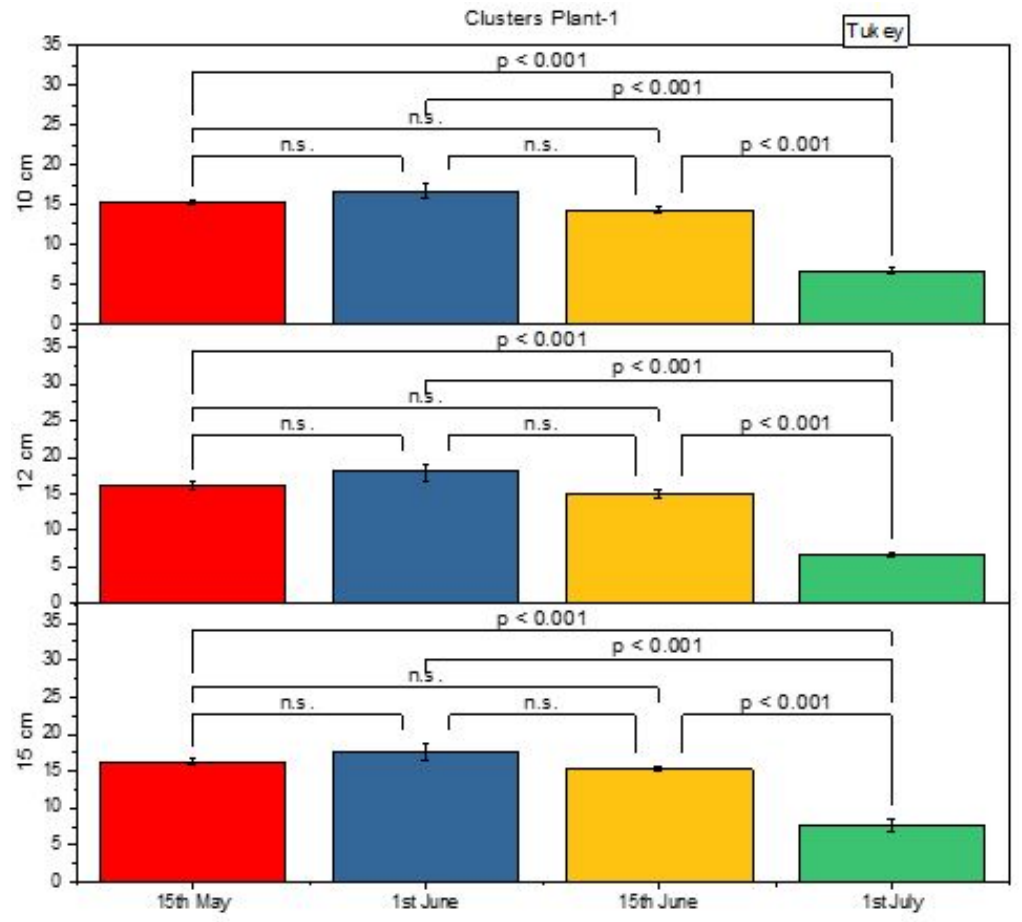

\section{Figure 3}

Impact of sowing times and planting spacing on cluster plant- 1 of cluster bean. The values are the mean of three replication. The error bars represent the standard error $(n=3)$. Within sowing time, the values are $p$ values computed by tukey test at $p<0.05$. 

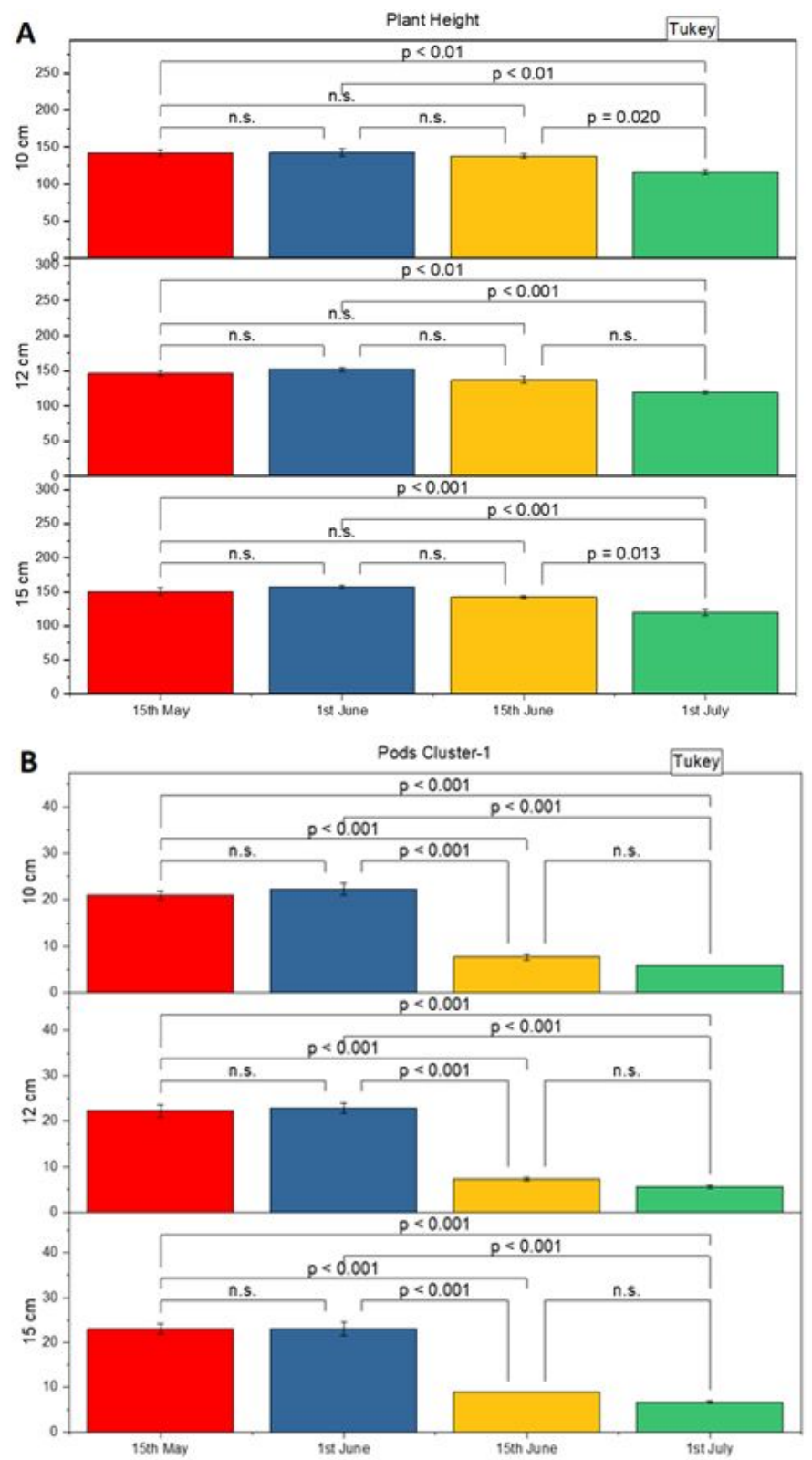

\section{Figure 4}

Impact of sowing times and planting spacing on plant height (A) and pods cluster-1 (B) of cluster bean. The values are the mean of three replication. The error bars represent the standard error $(n=3)$. Within sowing time, the values are $p$ values computed by tukey test at $p<0.05$. 

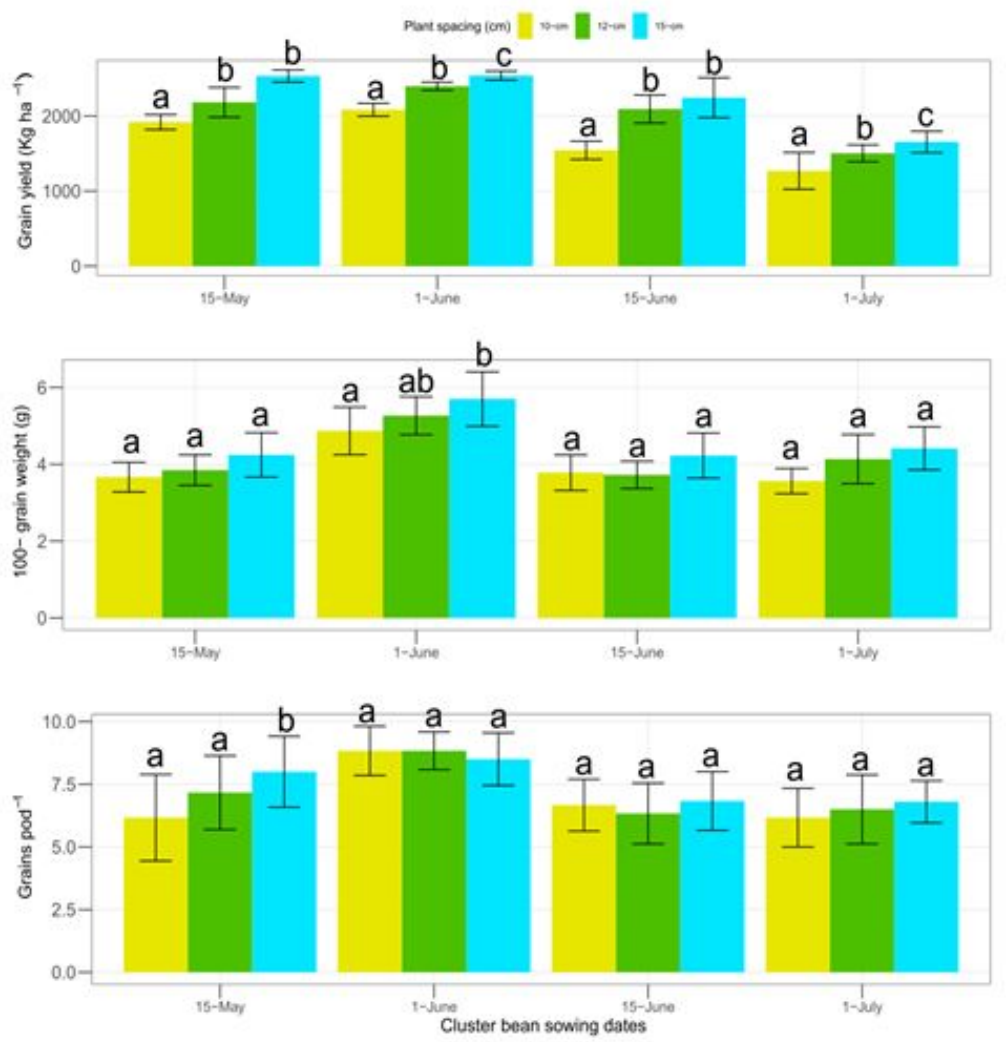

\section{Figure 5}

Impact of sowing times and planting spacing on grain yield, 100-grain weight, and grain pod-1 of cluster bean. The values are the mean of three replication. The error bars represent the standard deviation $(n=3)$. Within sowing time, the values with same letter $(s)$ are statistically non-significant at $p<0.05$. 

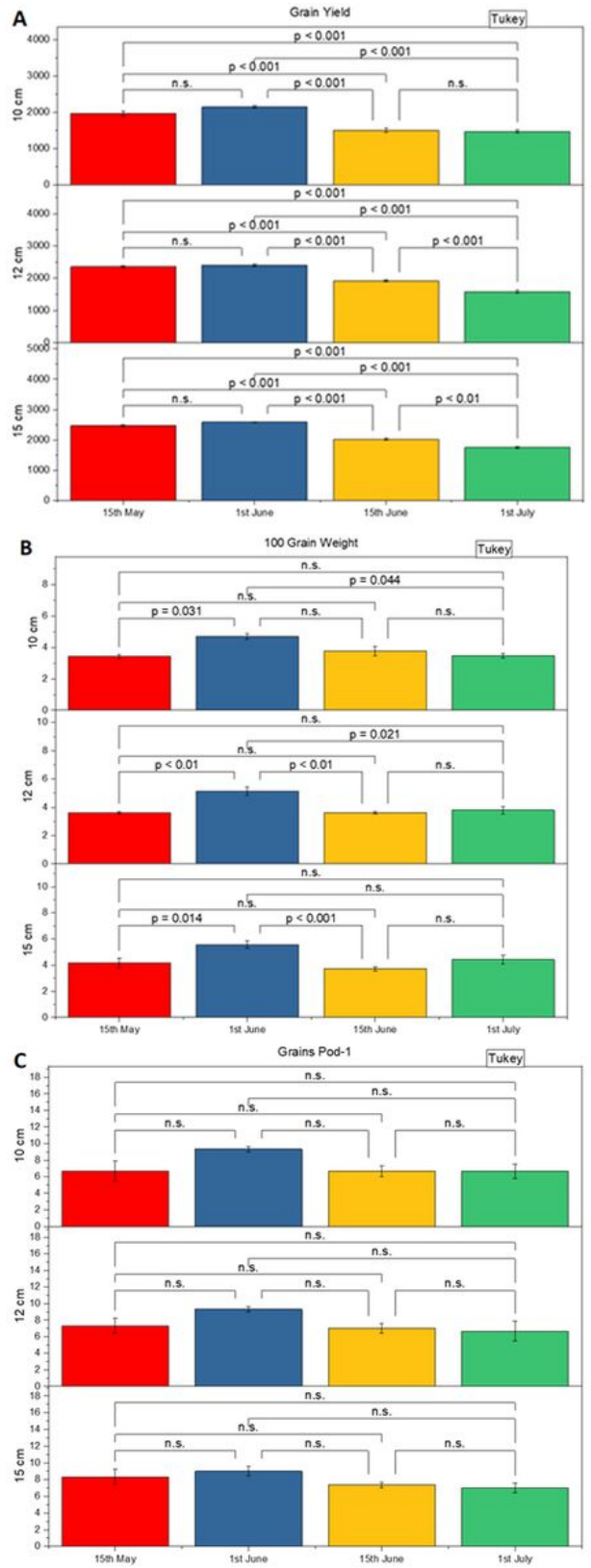

Figure 6

Impact of sowing times and planting spacing on grains yield (A), 100 grains weigh (B) and grains pod-1 (C) of cluster bean. The values are the mean of three replication. The error bars represent the standard error $(n=3)$. Within sowing time, the values are $p$ values computed by tukey test at $p<0.05$. 

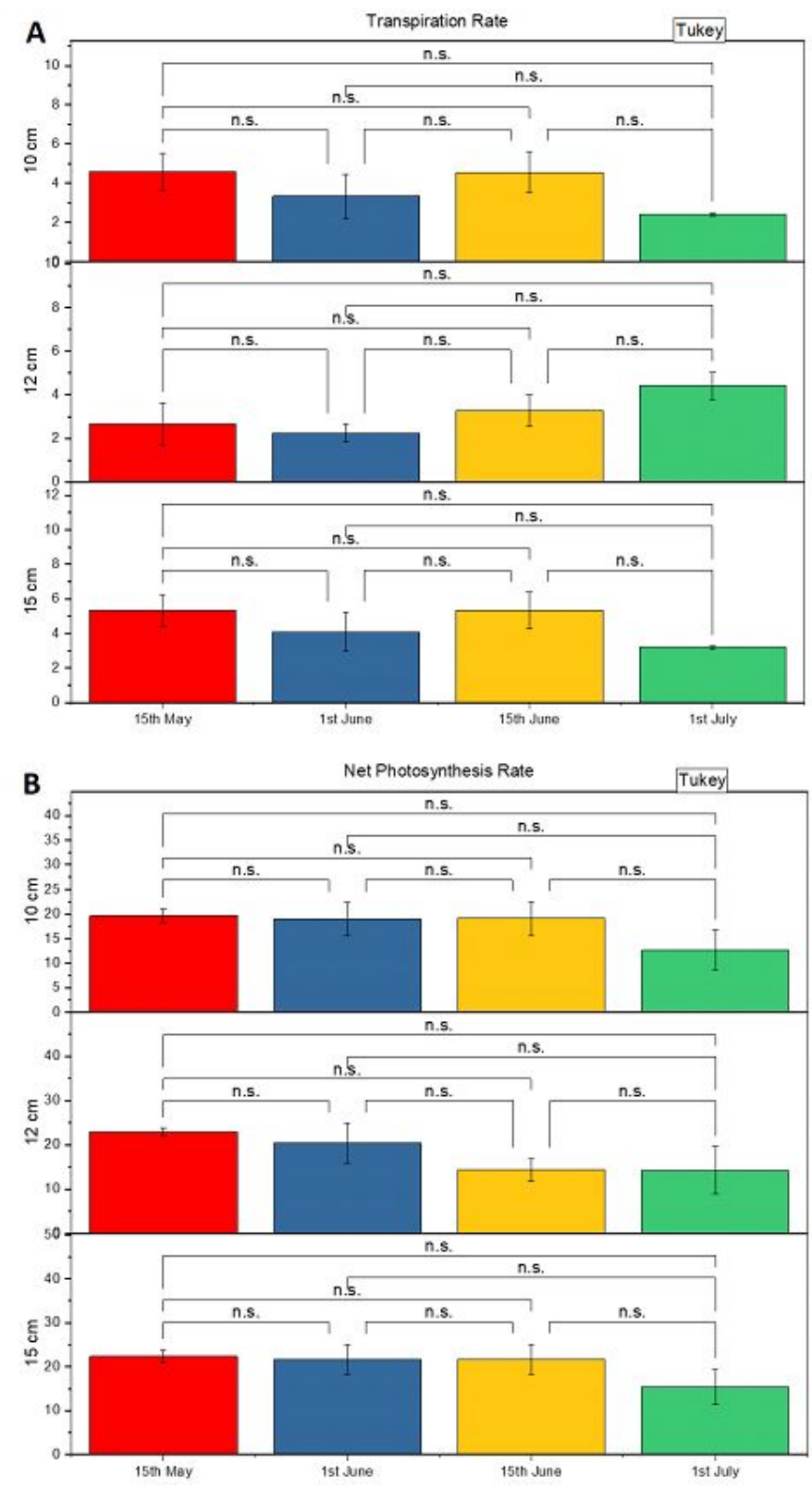

Figure 7

Impact of sowing times and planting spacing on transpiration rate (A) and photosynthetic rate (B) of cluster bean. The values are the mean of three replication. The error bars represent the standard error $(n=3)$. Within sowing time, the values are $p$ values computed by tukey test at $\mathrm{p}<0.05$. 

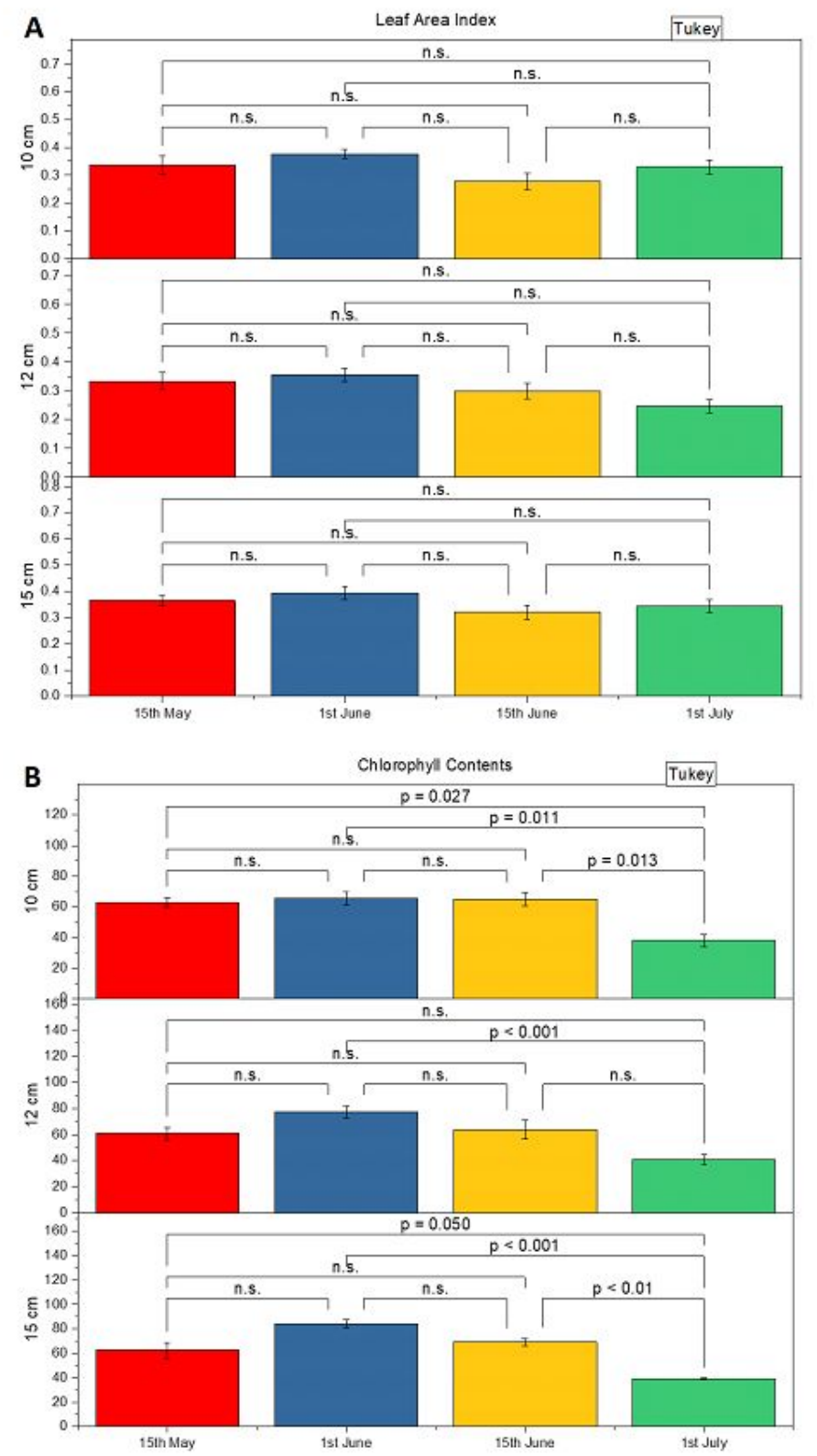

\section{Figure 8}

Impact of sowing times and planting spacing on leaf area index (A) chlorophyll contents (B) of cluster bean. The values are the mean of three replication. The error bars represent the standard error $(n=3)$. Within sowing time, the values are $p$ values computed by tukey test at $p<0.05$. 


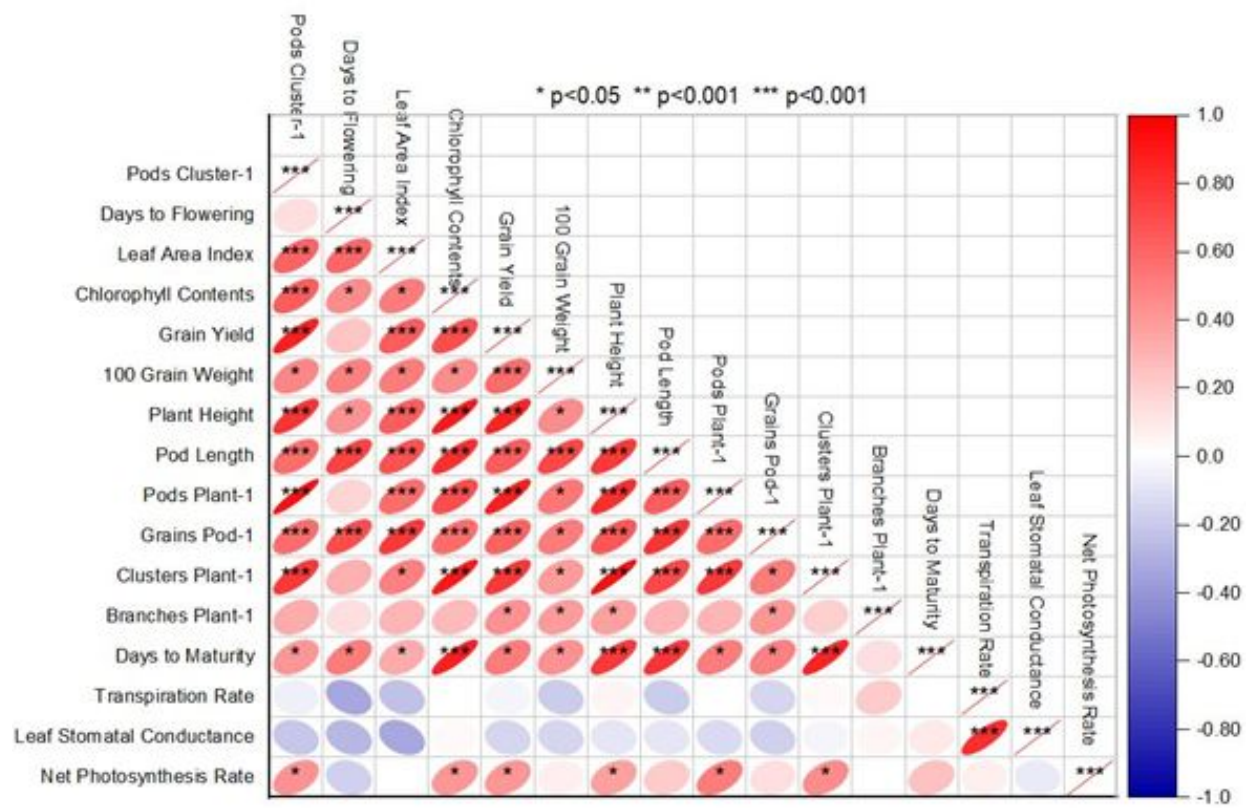

\section{Figure 9}

Pearson correlation for different growth and yield attributes 
A
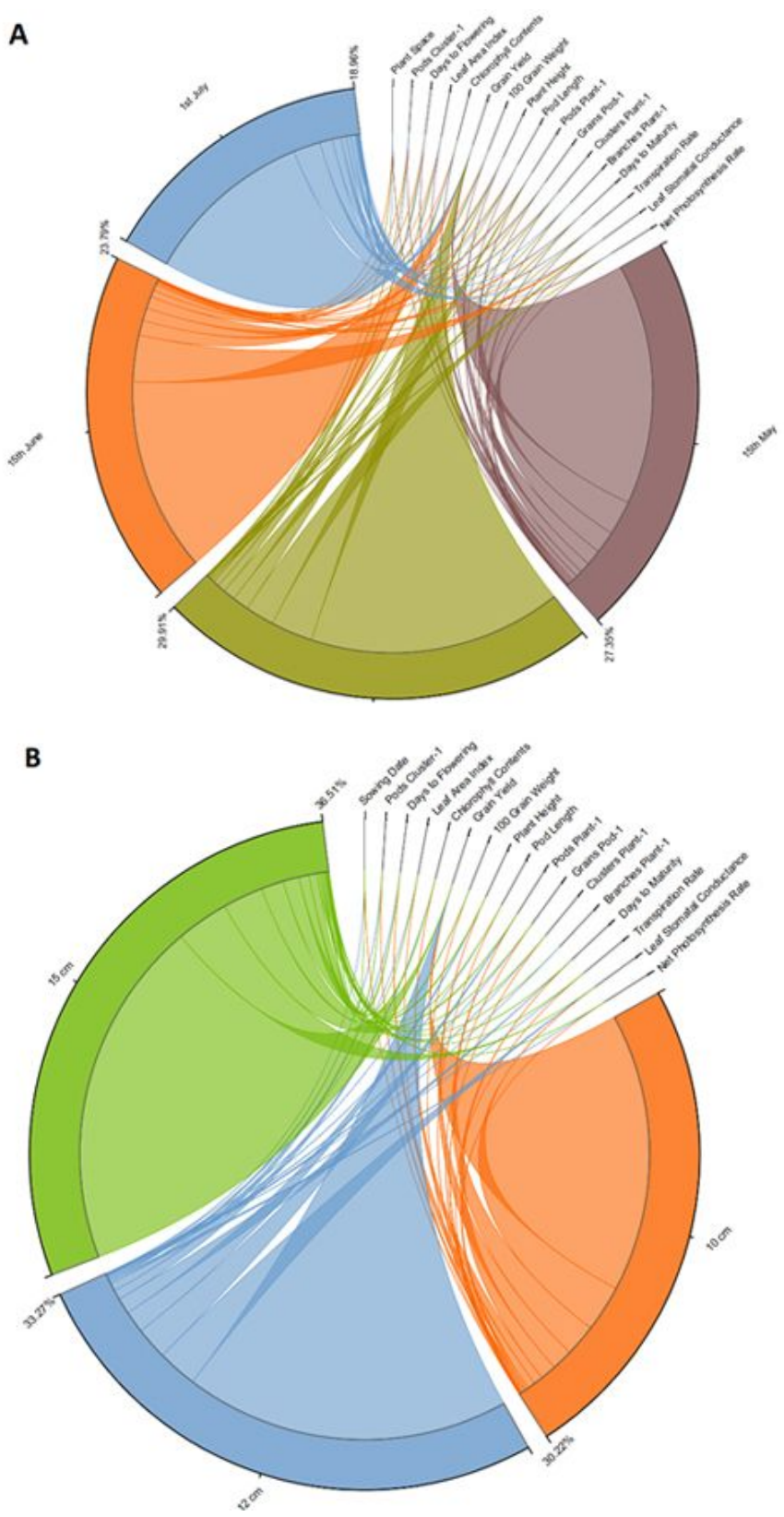

Figure 10

Chord diagram showing contribution of sowing date (A) plant spacing (B) in improvement of growth and yield attributes of cluster bean 